\title{
Bacteria are not the primary cause of bleaching in the Mediterranean coral Oculina patagonica
}

\author{
TD Ainsworth ${ }^{1}$, M Fine ${ }^{1,2}$, G Roff ${ }^{1}$ and O Hoegh-Guldberg ${ }^{1}$ \\ ${ }^{1}$ Centre for Marine Studies, and the ARC Centre of Excellence for Coral Reef Studies, The University \\ of Queensland, St Lucia, Queensland, Australia and ${ }^{2}$ Faculty of Life Sciences, Bar-Ilan University, \\ The Interuniversity Institute for Marine Science, Eilat, Israel
}

\begin{abstract}
Coral bleaching occurs when the endosymbiosis between corals and their symbionts disintegrates during stress. Mass coral bleaching events have increased over the past 20 years and are directly correlated with periods of warm sea temperatures. However, some hypotheses have suggested that reef-building corals bleach due to infection by bacterial pathogens. The 'Bacterial Bleaching' hypothesis is based on laboratory studies of the Mediterranean invading coral, Oculina patagonica, and has further generated conclusions such as the coral probiotic hypothesis and coral hologenome theory of evolution. We aimed to investigate the natural microbial ecology of $O$. patagonica during the annual bleaching using fluorescence in situ hybridization to map bacterial populations within the coral tissue layers, and found that the coral bleaches on the temperate rocky reefs of the Israeli coastline without the presence of Vibrio shiloi or bacterial penetration of its tissue layers. Bacterial communities were found associated with the endolithic layer of bleached coral regions, and a community dominance shift from an apparent cyanobacterial-dominated endolithic layer to an algal-dominated layer was found in bleached coral samples. While bacterial communities certainly play important roles in coral stasis and health, we suggest environmental stressors, such as those documented with reef-building corals, are the primary triggers leading to bleaching of $O$. patagonica and suggest that bacterial involvement in patterns of bleaching is that of opportunistic colonization.
\end{abstract}

The ISME Journal (2008) 2, 67-73; doi:10.1038/ismej.2007.88; published online 6 December 2007

Subject Category: microbe-microbe and microbe-host interactions

Keywords: coral bleaching; Oculina patagonica; bacteria; Vibrio shiloi

\section{Introduction}

Coral bleaching occurs when the symbiosis between corals and their endosymbionts (Symbiodinium spp) disintegrates in response to stress (Jokiel and Coles, 1977; Steen and Muscatine, 1987; Hoegh-Guldberg and Smith, 1989; Kleppel et al., 1989; Glynn and D’Croz, 1990; Lesser et al., 1990; Glynn, 1991; Hoegh-Guldberg, 1999; Leggat et al., 2006). The incidence of mass coral bleaching has increased over the past 20 years and is directly correlated with periods of exceptionally warm sea temperatures (Glynn, 1991; Hoegh-Guldberg, 1999). Projections using climate models suggest that sea temperatures may eventually rise above the current thermal

Correspondence: TD Ainsworth, Centre for Marine Studies, and the ARC Centre of Excellence for Coral Reef Studies, The University of Queensland, St Lucia, Queensland-4072, Australia. E-mail: t.ainsworth@uq.edu.au

Received 23 June 2007; revised 7 August 2007; accepted 24 September 2007; published online 6 December 2007 tolerances of corals at almost all sites worldwide and severely impact sustainability of coral reefs (Glynn, 1991; Hoegh-Guldberg, 1999; Hughes et al., 2003; Donner et al., 2005). It has been widely documented that during periods of warm sea surface temperatures, symbiont photosynthesis is reduced due to an increased susceptibility to photo-inhibition, which leads directly to active oxygen production and results in the breakdown of the symbiosis (Jokiel and Coles, 1977; Iglesias-Preito et al., 1992). Alternatively, recent studies have proposed that bacterial pathogens are the primary cause of bleaching in reef-building corals (Rosenberg and BenHaim, 2002; Rosenberg and Falkovitz, 2004; Rosenberg et al., 2007). The Bacterial Bleaching Hypothesis (Rosenberg and Ben-Haim, 2002; Rosenberg and Falkovitz, 2004) arose from studies in which the bacterium, Vibrio shiloi, was shown to cause the annual bleaching of the Mediterranean invading coral Oculina patagonica during warm summer months (Kushmaro et al., 1996, 1998). This hypothesis was extended to other corals and proposed as an 
alternative to climate change as the primary driver for the increase in mass coral bleaching over the past two decades (Rosenberg and Falkovitz, 2004).

$O$. patagonica bleaches annually in precisely midJune when water temperatures rise above $24^{\circ} \mathrm{C}$, bleaching then continues throughout the spring and summer, by which time water temperatures reach $32^{\circ} \mathrm{C}$ and up to $80 \%$ of the population has bleached (Kushmaro et al., 1998, 2001; Israely et al., 2001). V. shiloi has been reported, from laboratory studies, to become virulent at water temperatures of $24^{\circ} \mathrm{C}$, penetrating the coral and multiplying within the tissues (Kushmaro et al., 1998; Israely et al., 2001). Studies revealed that $V$. shiloi adheres to $\beta$-D-galactopyranoside receptors in the mucus of $O$. patagonica prior to penetrating the epithelial cells (Banin et al., 2000). V. shiloi then differentiates into a viable-but-not-culture-able form, multiplying and producing a proline-rich peptide toxin, which inhibits Symbiodinium photosystems (Banin et al., 2001a,b). The conclusions drawn from this $O$. patagonica/ $V$. shiloi model have been used as the basis to propose bacterial pathogenesis as the cause of global patterns of mass bleaching (Rosenberg and Ben-Haim, 2002; Rosenberg and Falkovitz, 2004; Reshef et al., 2006; Rosenberg et al., 2007). The present study aims to investigate the in situ bacterial involvement, and in situ coral microbial ecology, in ecological patterns of bleaching in $O$. patagonica across the Isreali coastline.

\section{Materials and methods}

O. patagonica was extensively monitored (over 140 samples) along the Mediterranean coast of Israel throughout the annual bleaching event in 2005 . Bleached colonies, as well as colonies with no apparent colour loss or bleaching were monitored. During the bleaching season (14 June until 22 August), bleached colonies and control unbleached colonies were sampled every 2 weeks at Sdot Yam. Bleached and unbleached colonies were sampled during bleaching season at other sites along the length of the Israeli Mediterranean coastline including Ashkelon, Bat Yam and Acziv. From each sampled colony, three replicate core samples were taken of each tissue region from each coral colony. Regions were designated either unbleached tissue or bleached tissue, bleached tissue cores were taken around the bleaching lesion to ensure both the bleached tissue and active region of bleaching were sampled. The bleaching lesion refers to the interface between the bleached and normally pigmented tissue. Coral cores were fixed in $4 \%$ paraformaldehyde in phosphate-buffered saline for $12 \mathrm{~h}$ and then stored at $4{ }^{\circ} \mathrm{C}$ in phosphate-buffered saline. Coral cores were decalcified in $20 \%(\mathrm{w} / \mathrm{v})$ EDTA in phosphate-buffered saline, and tissues were processed sequentially through 70, 80, 95 and $100 \%$ ethanol, three xylene and three paraffin washes, each for $40 \mathrm{~min}$, prior to paraffin embedding. Serial tissue sections $(4 \mu \mathrm{m})$ were collected onto Superfrost Plus slides (Menzel, Germany). Fluorescence in situ hybridization (FISH) was used with bacterial oligonucleotide probes in conventional FISH protocols (Manz et al., 2000; Amann et al., 1990, 2001; Amman et al., 1996) and coupled with spectral imaging (Ainsworth et al., 2006), to explore the identity and structural complexity of microbial communities associated with $O$. patagonica tissue layers. The technique provided imagery of the active bleaching and microbial community dynamics of the bleaching under field conditions. Photomicrographs of positive control samples of experimentally infected $O$. patagonica with V. shiloi (Rosenberg and Resef, pers. comm. (2005)) coupled with FISH and control tissues labelled with a $V$. shiloi-specific monoclonal antibody demonstrate the comparative microbial community dynamics associated with experimental pathogenic bleaching.

Intracellular bacterial proliferation was also examined via transmission electron microscopy

Cores of bleached and healthy $O$. patagonica colonies $(n=6)$ were collected between 2-5 m depth from reefs adjacent in Sdot Yam (latitude $32.4765^{\circ} \mathrm{N}$, longitude $34.8864^{\circ} \mathrm{E}$ ) on the Israeli coast in July 2005. Small fragments $\left(2 \mathrm{~cm}^{2}\right)$ from each colony were immediately fixed in $3 \%$ gluteraldehyde in $0.1 \mathrm{M}$ cacodylate buffer. Coral cores were decalcified in $20 \%$ EDTA at $4{ }^{\circ} \mathrm{C}$ (Ainsworth et al., 2006), and ultra thin $1 \mu \mathrm{m}$ tissue sections were stained using 1\% Toluidine blue (Sigma-Aldrich Pty Ltd, St Louis, MO, USA, catalogue no. 89640). To investigate general tissue structure and endosymbiont location samples were photographed using standard light microscopy, following which sample grids with ultra-thin sections were viewed in a transmission electron microscope (JEOL 1010) at acceleration voltage $90 \mathrm{kV}$ and images taken using the Megaview III Soft Imaging system.

\section{Results}

V. shiloi is not associated with $\mathrm{O}$. patagonica bleaching Bleaching of $O$. patagonica occurred along the Mediterranean coastline to the same extent as reported previously. Bleaching was observed throughout the summer period within coral colonies from Northern, mid and southern regions of the Isreali coastline. Bleaching was observed to begin in mid-June 2005 and continued throughout the summer months. However, the annual mass bleaching of $O$. patagonica along the coast was found to occur without the involvement of $V$. shiloi, Vibrio species or any bacterial penetration and proliferation within its tissue layers.

No evidence of bacterial populations was found associated with any of the 48 samples of bleached corals, 48 samples of unbleached tissues of corals 
Table 1 Number of coral colonies and replicate samples investigated of $O$. patagonica on the Israeli Eastern Mediterranean coastline

\begin{tabular}{lcccc}
\hline Sample type & No. of colonies & No. of replicates/colony & Total no. of samples & Min. total no. of FISH \\
\hline Unbleached colony & 16 & 3 & 48 & 144 \\
Bleaching lesion & 20 & 3 & 48 & 144 \\
Unbleached region & 20 & 3 & 48 & 144 \\
\hline
\end{tabular}

Abbreviation: FISH, fluorescence in situ hybridization.

Each replicate sample was individually probed with general bacterial probe mix, $\gamma$-proteobacterial probe and Vibrio sp. probe, each in situ was also photographed at replicated regions within the tissue sample at 20, 40 and 63 times magnification. Samples were also randomly selected and FISH analysis repeated.

undergoing bleaching or 48 samples healthy samples taken during this study (Table 1). Each replicate sample was individually probed with general bacterial probe mix, $\gamma$-proteobacterial probe and Vibrio sp probe, with a resulting 144 FISH experiments conducted on each region type. Each in situ was also photographed at replicated regions within the tissue sample at 20, 40 and 63 times magnification. Samples were also arbitrarily selected and FISH analysis repeated. Bacterial populations penetrating and/or multiplying were not found within either the epithelium or gastrodermis of the bleached regions or bleaching lesions of $O$. patagonica tissues using FISH (Figure 1). Samples were investigated with a range of bacterial probes, including EUB338mix (Manz et al., 2000; Amann et al., 1990, 2001; Amman et al., 1996), GAM 42a (Manz et al., 2000) and a marine Vibrio probe (Moreno et al., 1999), none of which labelled any bacterial populations within the tissue layers of bleached coral colonies (Figure 1). Significant intracellular bacterial populations were absent from all normal unbleached colony tissues and unbleached tissue regions of bleached colonies investigated within this study (Figure 1). Electron microscopy of bleached tissues also demonstrates a lack of intracellular bacterial proliferation (Figure 1).

FISH probes used on tissues of $O$. patagonica experimentally infected with $V$. shiloi (provided by Rosenberg and Resef, pers. comm. (2005)) demonstrated that bacterial proliferation could be identified within $O$. patagonica tissues pathogenbleached experimentally (Figure 2).

The only microbial communities interacting with and in close association with the tissue layers of field bleached corals were members of the endolithic community (Figures 1, 3 and 4). Endolithic communities were found underlying not only bleached lesions but also healthy coral tissues and healthy corals prior to bleaching. A shift in endolithic community dominance was observed associated with the coral bleaching, with communities dominated by cyanobacterial members (based on binding of EUBmix probes and presence of chlorophyll pigment spectral signature) in corals prior to bleaching (Figure 4) being replaced by communities dominated by green algae such as Ostreobium spp in bleached regions (Figure 3).

\section{Discussion}

It can be stated unambiguously that $V$. shiloi is not involved in, nor is currently the primary cause of, the continued annual bleaching of $O$. patagonica of the Eastern Mediterranean. Not only did bleaching occur without the involvement of $V$. shiloi in 2005, but the subsequent death of bleached coral colonies took place without Vibrio sp being present. A lack of vibrio-driven bleaching in ecological scenarios is also supported by the recent lack of bacterial bleaching found with in experimental conditions (Reshef et al., 2006). We therefore suggest that there is no evidence to support a primary role of bacteria in causing coral bleaching in the system used, as basis, for the Bacterial Bleaching Hypothesis, or evidence to suggest microbial control techniques could be effective to treat or prevent mass coral bleaching.

The only detectable microbial communities interacting with and in close association with the tissue layers were members of the endolithic community. Here, endolithic communities are found underlying not only bleached lesions but also healthy coral tissues and healthy corals prior to bleaching. Interestingly, a shift in endolithic community dominance occurs associated with the coral bleaching, where communities dominated by cyanobacterial members in corals prior to bleaching are replaced by communities dominated by green algae during the coral bleaching. Koren and Rosenberg (2006) describe high diversity of bacterial communities associated within coral tissues of $O$. patagonica. Here, it can be seen that the skeleton of the coral may in fact be a region where the high bacterial diversity of $O$. patagonica is located. This shift in the microbial community associated with $O$. patagonica highlights the potential importance of the diverse and complex interactions between the many associated components of this coral holobiont and its unique qualities when compared to reef-building corals.

The role of the endolithic community of $O$. patagonica, particularly during increasing seawater temperatures and environmental stress, and that of the community shift during bleaching evoke questions as to the relationship the microbial community has in the stability of the coral holobiont, as well as the potential sources of opportunistic pathogens. 

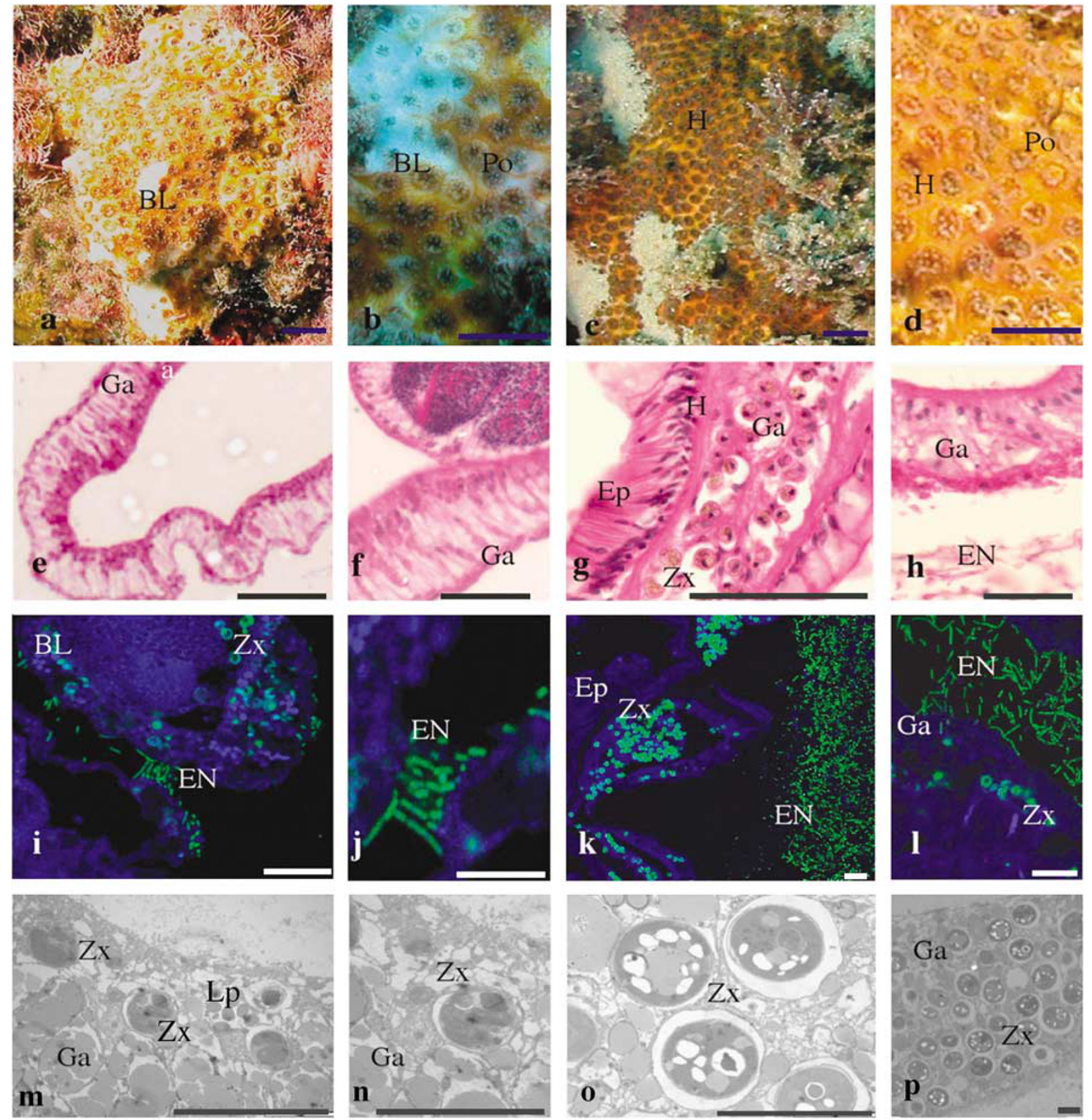

Figure 1 Bleached $(\mathbf{a}, \mathbf{b})$ and healthy $(\mathbf{c}, \mathbf{d})$ O. patagonica colonies from the Israeli Mediterranean coastline during the summer of 2005. Bleached colonies are evident by the white lesions (b) and areas of low density of endosymbiotic dinoflagellates (e, f). Large populations of endolithic microbial communities were found in both bleached (i, j) and healthy corals, (h, k, l) but no Vibrio sp as evident by the lack of probe staining in either bleached $(\mathbf{i}, \mathbf{j})$ or healthy colonies $(\mathbf{k}, \mathbf{l})$, as also seen using transmission electron microscopy of bleached (m, $\mathbf{n})$ and healthy tissues $(\mathbf{o}, \mathbf{p})$. Scale, $1 \mathrm{~cm}(\mathbf{a}-\mathbf{d}), 50 \mu \mathrm{m}(\mathbf{e}-\mathbf{l}), 1 \mu \mathrm{m}(\mathbf{m}-\mathbf{p})$. BL, bleaching lesion; H, healthy tissue; Zx, endosymbiotic dinoflagellates; En, endolithic microbial population; Po, Polyp.; Ga, gastroderm.

Complex biofilms, such as microbial mats, represent rich, structured and productive microbial ecosystems (Guerrero et al., 2002). Phototrophic biofilms have previously been shown to colonize hard substrate in aquatic and terrestrial ecosystems and contribute large quantities of total fixed carbon to the ecosystem (Guerrero et al., 2002; de la Torre et al., 2003). The role of the endolithic community of the coral O. patagonica and the overall community dynamics associated with stress, bleaching and disease remains to be determined. At this point, it is clear that this layer is far from passive, as demonstrated by the shift occurring during bleaching, and may play a role in a number of key processes.

While microbial populations play important roles governing coral stasis, as evident by the coral holobiont model (Rohwer et al., 2002) and within coral diseases, the importance of opportunistic pathogenesis and the susceptibility of corals related 

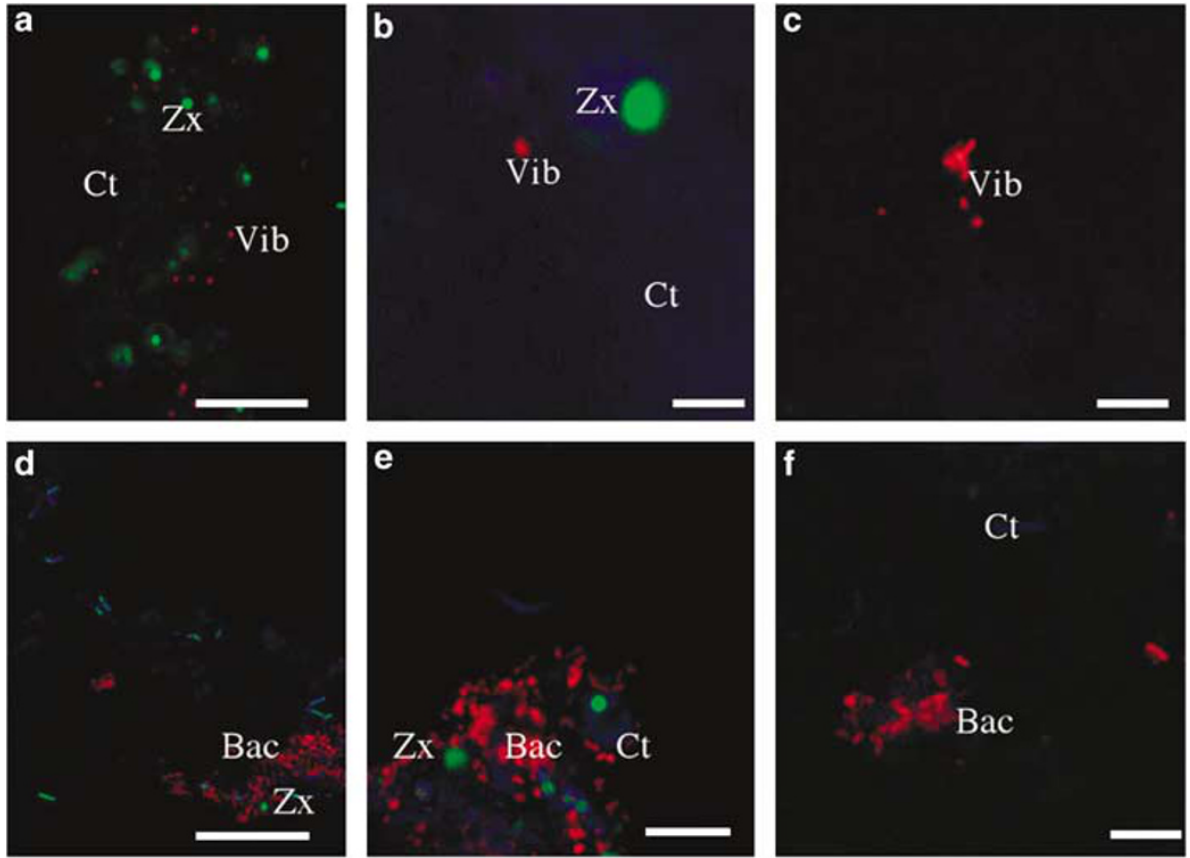

Figure 2 FISH of $O$. patagonica infected with cultured $V$. shiloi in a laboratory based infection experiment. V. shiloi is evident within the tissue layers using a $V$. shiloi-specific monoclonal antibody $(\mathbf{a}-\mathbf{c})$ and also using EUBmix 338 (d-f) universal bacterial probe. Scale, $5 \mu$ m. Vib, bacteria identified by V. shiloi Mab (red); Bac, bacteria identified by EUB probe (red); Zx, endosymbiotic dinoflagellates (green); Ct, coral tissue (blue).
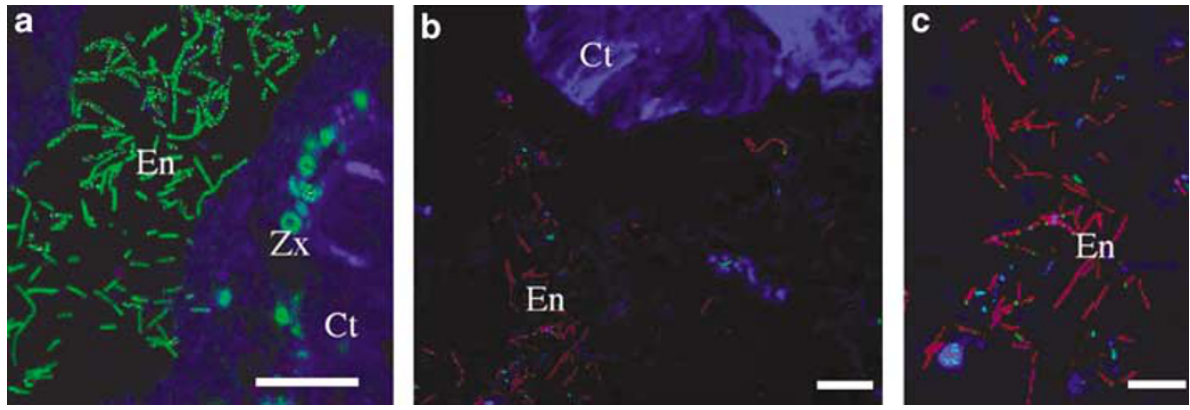

Figure 3 FISH and subtractive spectral imaging of filamentous endolithic communities associated with $O$. patagonica. Subtractive spectral imaging removes the innate chlorophyll-conferred fluorescence (spectral emittance region 575-625 nm) (a) and indicates positive probe binding of the cy-3 fluorescence (spectral emission at $543 \mathrm{~nm}$ ) of EUBmix probe (b, c) and identification as bacterial (potentially cyanobacterial communities). Scale, $50 \mu \mathrm{m}$. BL, bleaching lesion; H, healthy tissue; Zx, endosymbiotic dinoflagellates; EL, endolithic microbial population.
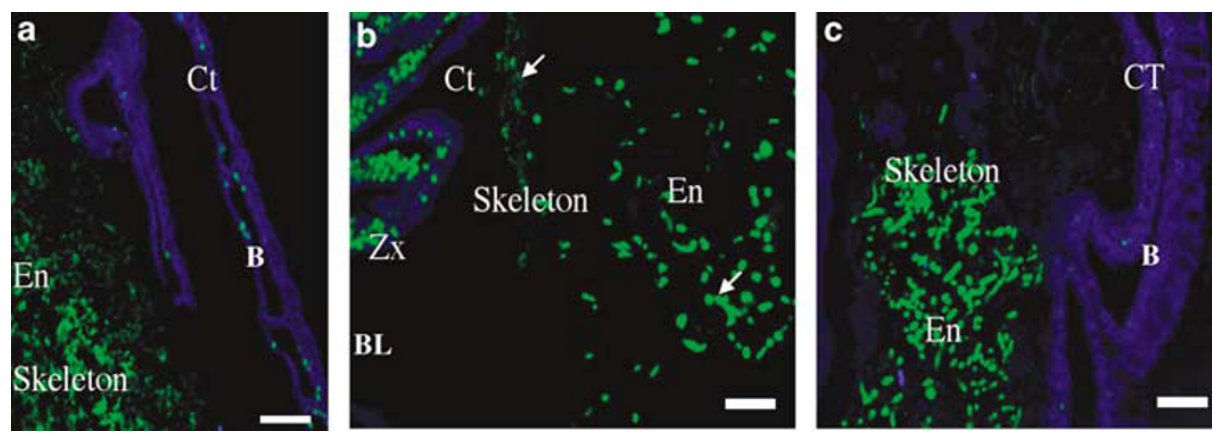

Figure 4 Bleaching of $O$. patagonica tissues in summer of 2005 where endosymbiotic dinoflagellates (Zx) are in low densities in bleached tissue regions (a, c), compared to high densities in unbleached tissue regions adjacent to bleached tissues (b), a change in endolithics dominance to algal communities associated with bleaching lesions, evident by the large size of the algal dominant endolithic population (EL). Scale, $50 \mu \mathrm{m}$. BL, bleaching lesion; H healthy tissue; Zx Endosymbiotic dinoflagellates; En, endolithic microbial population. Arrowheads indicate different sizes of endolithic community members. 
to primary environmental stress is an important question that requires further study. The role of opportunistic pathogens should also be considered while suggesting the application of bacteriophages or microbial treatments of coral reefs during mass bleaching events and disease. If bacteria do not play a primary but rather a secondary role during coral bleaching or some diseases (in that corals are susceptible to microbial attack during stress), it needs to be determined if the use of microbial remedies at local or regional scales could reduce the impact of disease events in what are highly diverse, interconnected and complex microbial environments. This may further be supported by the discovery of a widely distributed and proposed coral pathogen Vibrio coralliilyticus, which causes the lysis of tissues and whitening of tropical corals (presumably via loss of tissue and exposure of the coral skeleton) during increased seawater temperatures (Ben-Haim and Rosenberg, 2002; Ben-Haim et al., 2003a,b). Bourne and Munn (2005) propose the wide distribution of this bacterium and its association with healthy coral may highlight its opportunistic rather than primary pathogenic role. In proposals of bacterial pathogenesis related to coral bleaching a clear and accurate differentiation of the cellular level changes associated with the coral bleaching in ecologically relevant scenarios is important. Differentiation of the cellular causes of whitening of coral colonies (exposure of the coral skeleton) as opposed to coral bleaching (loss of endosymbiotic algae or its associated pigments from host tissue) and the cellular mechanisms underlying these visual changes is imperative in accurately determining the cause of coral death. This is needed if we have to understand the role or microbial communities in the patterns of tissue loss and bleaching.

The findings of this study on the lack of pathogenic $V$. shiloi or bacterial interaction associated with the bleaching of $O$. patagonica are important in that they raise questions on hypotheses of bacterial mass coral bleaching (Rosenberg and Ben-Haim, 2002; Rosenberg and Falkovitz, 2004; Reshef et al., 2006) and coral hologenome evolution (Rosenberg et al., 2007). The probiotic hypothesis (Reshef et al., 2006) and the coral hologenome theory of evolution (Rosenberg et al., 2007) state that corals have the ability for rapid evolution in a changing environment by altering their microbial partners to overcome adverse environmental conditions and disease. However, the continued active annual bleaching of $O$. patagonica in the absence of $V$. shiloi, in the same manner as previous reports, suggests that while the microbial population has changed, there is no apparent microbial influence over patterns of coral bleaching. As has been the case for the past decade, bleaching of $O$. patagonica along the coast of Israel continues, beginning precisely in mid-June and continuing through the summer months until coral colony mortalities occur in mid-August.

As such, our study also suggests that caution is required for laboratory studies investigating bacter- ial pathogenesis with aquaria maintained or pre-stressed corals not held under normal environmental conditions. Rosenberg et al. (2007) report on a newly occurring short-term adherence and penetration of $V$. shiloi cultures to aquaria-maintained O. patagonica; however, our field-based survey was unable to detect any Vibrio spp adherence to O. patagonica. The study of Kline et al. (2006) shows that bacterial cultures from healthy corals when applied to corals in aquaria experiments caused a doubling of the normal bacterial load, which leads to coral mortality. Documenting the natural microbial community variability that exists in reef systems and how this may vary in contained systems is crucial in determining the impact and role of coral-associated communities not only in coral health but also during stress and disease.

\section{Acknowledgements}

We thank Professor Eugene Rosenberg for support, assistance and guidance throughout all phases of this research and manuscript preparation. We also thank Professor Yossi Loya and Dr Esti Kramasky-Winter for assistance during the histopathology analysis, and Ms Dorothea Burgess for conceptual support. We also thank the ARC Centre of Excellence for Coral Reef Studies (http://www.coralcoe.org.au/) and The GEF Coral Reef Targeted Research Program (http://www.gefcoral.org) for supporting this research project.

\section{References}

Ainsworth TD, Fine M, Blackal L, Hoegh-Guldberg O. (2006). Fluorescence in situ hybridisation and spectral imaging of coral-associated bacterial communities. Appl Environ Microbiol 72: 3016-3020.

Amann R, Fuchs BM, Behrens S. (2001). The identification of micro-organisms by fluorescence in situ hybridisation. Curr Opin Biotech 12: 231-236.

Amann RI, Binder BJ, Olson RJ, Chisholm SW, Devereux R, Stahl A. (1990). Combination of 16S rRNA-targeted oligonucleotide probes with flow cytometry for analysing mixed microbial populations. Appl Environ Microbiol 56: 1919-1925.

Amman R, Snaidr J, Wagner M, Ludwig W, Scleifer KH. (1996). In situ visualisation of high genetic diversity in a natural microbial community. J Bacteriol 178: 3496-3500.

Banin E, Israely T, Fine M, Loya Y, Rosenberg E. (2001a). Role of endosymbiotic zooxanthellae and coral mucus in the adhesion of coral bleaching pathogen Vibrio shiloi to its host. FEMS Micro Lett 199: 33-37.

Banin E, Israely T, Kushmaro A, Loya Y, Orr E, Rosenberg E. (2000). Penetration of the coral-bleaching bacterium Vibrio shiloi into Oculina patagonica. Appl Environ Microbiol 66: 3031-3036.

Banin E, Khare SK, Naider F, Rosenberg E. (2001b). Proline-rich peptide from coral pathogen Vibrio shiloi that inhibits photosynthesis of zooxanthallae. Appl Environ Microbiol 76: 1536-1541. 
Ben-Haim Y, Rosenberg E. (2002). A novel Vibriosp pathogen of the coral Pocillopora damicornis. Mar Biol 141: 47-55.

Ben-Haim Y, Thompson FL, Thomposon CC, Cnockaert MC, Hoste B, Swings J et al. (2003a). Vibrio coralliilyticus sp. nov., a temperature-dependent pathogen of the coral Pocillopora damicornis. Int J Sys Evol Microbiol 55: 309-315.

Ben-Haim Y, Zicherman-Keren M, Rosenberg E. (2003b). Temperature-related bleaching and lysis of the coral Pocillopora damicornis by the novel pathogen Vibrio coralliilyticus. Appl Environ Microbiol 69: 4236-4242.

Bourne D, Munn CB. (2005). Diversity of bacteria associated with the coral Pocillopora damicornis from the Great Barrier Reef. Env Micro 7: 1162-1174.

de la Torre JR, Goebel BM, Friedmann EI, Pace NR. (2003). Microbial diversity of crytoendolithic communities from Mc Murdo Dry Valles, Antarctic. Appl Environ Microbiol 69: 3858-3867.

Donner SD, Skirving WJ, Little CM, Oppenheimer M, Hoegh-Guldberg O. (2005). Global assessment of coral bleaching and required rates of adaptation under climate change. Global change Biol 11: 2251-2265.

Glynn P, D’Croz L. (1990). Experimental evidence for high temperature stress as the cause of El Nino-coincident coral mortality. Coral Reefs 8: 191-192.

Glynn PW. (1991). Coral-reef bleaching in the 1980's and possible connections with global warming. Trends Ecol Evol 6: 175-179.

Guerrero R, Piqueras M, Berlanga M. (2002). Microbial mats and the search for minimal ecosystems. Int Microbiol 5: 177-188.

Hoegh-Guldberg O. (1999). Coral bleaching, climate change and the future of the world's coral reef. Mar Freshw Res 50: 839-866.

Hoegh-Guldberg O, Smith GJ. (1989). The effect of sudden changes in temperature, light and salinity of population density and export of zooxanthallae from the reef corals Seriatopora hysterix and Stylophora pistillata. J Exp Mar Biol Ecol 129: 270-303.

Hughes TP, Baird AH, Bellwood DR, Card M, Connolly SR, Folke C et al. (2003). Climate change, human impacts and the resilience of Coral Reefs. Science 301: 929-933.

Iglesias-Preito R, Matta JL, Robins WA, Trench RK. (1992). Photosynthetic response to elevated-temperature in the symbiotic dinoflagellates Symbiodnium microadriaticum in culture. Proc Natl Acad Sci USA 89: 10302-10305.

Israely T, Banin E, Rosenberg E. (2001). Growth, differentiation and death of Vibrio shiloi in coral tissue as a function of seawater temperature. Aquat Microb Ecol 24: 1-8.

Jokiel PL, Coles SL. (1977). Effects of temperature on the mortality and growth of Hawaiian and other Indopacific reef corals to elevated temperature. Pac Sci 28: $1-18$.
Kleppel GS, Dodge RE, Reese CJ. (1989). Changes in pigmentation associated with the bleaching of stony corals. Limnol Oceanogr 34: 131-135.

Kline D, Kuntz NM, Breitart M, Knowlton N, Rowher F. (2006). Role of elevated organic carbon levels and microbial activity in coral mortality. Mar Ecol Prog Ser 314: 119-125.

Koren O, Rosenberg E. (2006). Bacteria associated with mucus and tissues of the Coral Oculina patagonica in summer and winter. App Env Micro Vol 72: 5254-5259.

Kushmaro A, Bani E, Loya Y, Stackebrandt E, Rosenberg E. (2001). Vibrio shiloi sp nov the causative agent of bleaching of the coral Oculina patagonica. Int J Syst Evol Micro 51: 1383-1388.

Kushmaro A, Loya Y, Fine M, Rosenberg E. (1996). Bacterial infection and coral bleaching. Nature 380: 396.

Kushmaro A, Rosenberg E, Fine M, Ben-Haim Y, Loya Y. (1998). Effect of temperature on bleaching of the coral Oculina patagonica by Vibrio shiloi AK-1. Mar Ecol Prog Ser 171: 131-137.

Leggat W, Ainsworth TD, Dove S, Hoegh-Guldberg O. (2006). Aerial exposure influences coral bleaching patterns. Coral Reefs 25: 452.

Lesser MP, Stochaj WR, Tapley DW, Shick JM. (1990). Bleaching in coral reef anthozoans: effects of irradiance, ultraviolet radiation and temperature on the activities of protective enzymes against active oxygen. Coral Reefs 8: 225-232.

Manz W, Arp G, Schumann-Kindel G, Szemzyke U, Reitner J. (2000). Widefield deconvolution epifluorescence microscopy combined with fluorescence in situ hybridisation reveals the spatial arrangement of bacteria in sponge tissue. J Microbiol Methods 40: 125-134.

Moreno Y, Arias CR, Meier H, Garay E, Aznar R. (1999). In situ analysis of the bacterial communities associated to farmed eel by whole-cell hybridisation. Lett Appl Micro 29: 160-165.

Reshef L, Koren O, Loya Y, Rosenberg IZ, Rosenberg E. (2006). The coral probiotic hypothesis. Env Micro 8 2068-2073.

Rohwer F, Seguritan V, Azam F, Knowlton N. (2002). Diversity and distribution of coral-associated bacteria. Mar Ecol Prog Ser 243: 1-10.

Rosenberg E, Ben-Haim Y. (2002). Microbial diseases of corals and global warming. Environ Micro 4: 318-326.

Rosenberg E, Falkovitz L. (2004). The Vibrio shiloi/ Oculina patagonica model system of coral bleaching. Annu Rev Micro 58: 143-159.

Rosenberg E, Koren O, Resef L, Efrony R, Rosenberg I-K. (2007). The role of micro-organisms in coral health, disease and evolution. Nat Rev Micro 5: 355-362.

Steen RG, Muscatine L. (1987). Low temperature evokes rapid exocytosis of symbiotic algae by a sea anemone. Biol Bull 172: 246-263. 